Sains Malaysiana 51(2)(2022): 577-583

http://doi.org/10.17576/jsm-2022-5102-21

\title{
Human Umbilical Cord Mesenchymal Stem Cells Inhibit Coronary Artery Injury in Mice with Lactobacillus casei Wall Extract-Induced Kawasaki Disease
}

(Sel Stem Mesenkima Tali Pusat Manusia Menghalang Kecederaan Arteri Koronari pada Tikus dengan Penyakit Kawasaki yang Disebabkan oleh Ekstrak Dinding Lactobacillus casei)

\author{
Hua Guo, Fuyong Jiao, Xiaoyong Zhang, Yangmeng Feng, Yang LiU, Daoyan Liang, Xiaohua Yan \& \\ HAIXIANG ZHANG*
}

\begin{abstract}
Kawasaki disease (KD) is a serious threat to children's physical and mental health. This study investigated the effect of human umbilical cord mesenchymal stem cells (hUC-MSCS) on KD coronary arteritis induced by Lactobacillus casei wall extract ( $L C W E)$ in an animal model. Sixty BALB/C mice were randomly assigned to three groups $(n=20$ mice per group). Mice in the model and stem-cell groups were injected with LCWE, while the control-group mice were injected with phosphate-buffered saline (PBS) for 2 days. At day 16 of modeling, PBS was injected into the control and model-group mice, and hUC-MSCs were injected into the stem-cell group mice for 10 days. At days 4, 15, 26, and 32 of modeling, echocardiography and histopathology were performed to examine the cardiac structure and the morphological changes in the coronary arteries in each group. B-ultrasonography showed that $57.5 \%(23 / 40)$ of the mice had coronary artery lesions, of which 5\% (2/40) had right coronary artery aneurysm, 27.5\% (11/40) had coronary artery wall thickening, a widened inner diameter of the main artery of the left coronary artery, and thickened intima. Histopathology showed slight swelling of the epicardium of the aortic valve, mitral valve, right ventricle, and atrium, as well as scattered infiltration of a few neutrophils. Following hUC-MSCs intervention treatment, B-ultrasonography showed a decrease in the main coronary artery diameter, while histopathology showed no obvious vascular inflammatory reaction or other obvious abnormalities. These findings highlight that hUC-MSCs inhibit coronary artery injury in animal models of KD induced by LCWE.
\end{abstract}

Keywords: Coronary artery; human umbilical cord mesenchymal stem cells; Kawasaki disease; Lactobacillus casei wall extract

\section{ABSTRAK}

Penyakit Kawasaki (KD) adalah ancaman serius kepada kesihatan fizikal dan mental kanak-kanak. Kajian ini mengkaji kesan sel stem mesenkima tali pusat manusia (hUC-MSCS) pada arteritis koronari KD yang disebabkan oleh ekstrak dinding Lactobacillus casei (LCWE) dalam model haiwan. Enam puluh tikus BALB/C secara rawak diberikan kepada tiga kumpulan ( $n=20$ tikus setiap kumpulan). Tikus dalam model dan kumpulan sel stem telah disuntik dengan LCWE, manakala tikus kumpulan kawalan disuntik dengan garam penampan fosfat (PBS) selama 2 hari. Pada hari ke-16 pemodelan, PBS disuntik ke dalam tikus kawalan dan kumpulan model dan hUC-MSC disuntik ke dalam tikus kumpulan sel stem selama 10 hari. Pada hari 4, 15, 26 dan 32 pemodelan, ekokardiografi dan histopatologi dilakukan untuk memeriksa struktur jantung dan perubahan morfologi dalam arteri koronari dalam setiap kumpulan. B-ultrasonografi menunjukkan bahawa 57.5\% (23/40) daripada tikus mempunyai lesi arteri koronari dengan 5\% (2/40) mempunyai aneurisma arteri koronari kanan, 27.5\% (11/40) mempunyai penebalan dinding arteri koronari, diameter dalaman arteri utama arteri koronari kiri melebar dan intima yang menebal. Histopatologi menunjukkan sedikit pembengkakan epikardium injap aorta, injap mitral, ventrikel kanan dan atrium, serta penyusupan bertaburan beberapa neutrofil. Berikutan rawatan intervensi hUC-MSCs, B-ultrasonografi menunjukkan penurunan dalam diameter arteri koronari utama, manakala histopatologi tidak menunjukkan tindak balas keradangan vaskular yang jelas atau keabnormalan lain yang jelas. Penemuan ini menyerlahkan bahawa hUC-MSC menghalang kecederaan arteri koronari dalam model haiwan KD yang disebabkan oleh LCWE.

Kata kunci: Arteri koronari; ekstrak dinding Lactobacillus casei; penyakit Kawasaki; sel stem mesenkima tali pusat manusia 


\section{INTRODUCTION}

Kawasaki disease (KD), also known as skin mucous membrane lymph node syndrome, is a serious threat to children's physical and mental health and is more common in children under the age of 5 years. The main pathological changes of KD include systemic nonspecific vasculitis and infringement of the coronary artery, while some children also present with coronary aneurysm formation, coronary artery stenosis or thrombosis, and even myocardial infarction (Lo 2020; Nakayama et al. 2020). Up to $25 \%$ of untreated children with KD develop coronary artery disease, leading to myocardial infarction, sudden death, and ischemic heart disease, which is the main cause of acquired heart disease in children. Most children with KD can obtain a good therapeutic effect from conventional treatment; however, some children show resistance to the first-line agent $\gamma$-globulin and require intravenous immunoglobulin and (or) hormonal therapy. Among them, some children with severe coronary artery damage (such as coronary artery tumors) need long-term or lifelong anticoagulant drugs; however, these have poor efficacy, and the patients require constant monitoring for critical cardiovascular events (Dallaire et al. 2017; Lo $\&$ Newburger 2018). This is not only a long-term concern and worry for the patients and their families but also a problematic issue that requires further study.

At present, the pathogenesis of KD is unclear; however, the establishment of an experimental animal model can be used to observe the therapeutic effect of different drugs on vasculitis and help to determine a more effective treatment. Noval Rivas et al. (2017) and Qin et al. (2006) used L. casei cell wall extract (LCWE) to induce coronary inflammation in mice, while Tanaka et al. (2020) and Yan et al. (2012) used Candida albicans water-soluble fraction (CAWS) to induce coronary artery pathological changes in mice is similar to KD coronary inflammation. Together, these previous studies have laid a solid foundation for the research and treatment of KD. Human umbilical cord mesenchymal stem cells (hUC-MSCs), which are derived from Waltongren's gum in the fetal umbilical cord, have the advantages of no ethical dispute, wide source, easy access, low antigenicity, and multidifferentiation potential, and are one of the critical seed cells in tissue engineering (Muheremu et al. 2016). According to different induction conditions, hUC-MSCs can differentiate into bone cells, chondrocytes, cardiomyocytes, hepatocytes, and islet cells, among others, bringing new treatment directions for neurological diseases, cardiovascular diseases, diabetes, and liver and other diseases ( $\mathrm{Li}$ et al. 2017;
Perea-Gil et al. 2015). At present, hUC-MSCs have been used in the research and treatment of immune and cardiovascular system diseases (Abbaszadeh et al. 2020; Suzuki et al. 2017); however, the clinical use of hUCMSCs to repair coronary artery lesions caused by KD has not yet been reported. Therefore, in this study, LCWE was used as an inducer to construct a BALB/C mouse model of $\mathrm{KD}$, and hUC-MSCs were used to repair coronary artery lesions in animal models of KD for the first time. The results of our study will provide an experimental basis for exploring the mechanism of hUC-MSCs used in the clinical treatment of coronary artery damage in patients with KD.

\section{Materials ANd Methods}

ANIMALS

Female 10-week-old BALB/C mice (Production license SCXK [Beijing] 2016-0006, sales license SYXK [Shaanxi] 2012-005), with a weight range of $17 \pm$ $0.5 \mathrm{~g}$, were purchased from Beijing Viton Lihua Experimental Animal Technology Co., Ltd., for use in this study.

\section{REAGENTS}

L. casei was purchased from Beina Cell Biological Preservation management Center (No. 134415); MRS (DeMan, Rogosa, Sharpe) broth medium was purchased from Hangzhou Best Biotechnology Co., Ltd.; and RNAse, deoxyribonuclease I (DNAse I), Trypsin, Rhamnose standard, and sodium dodecyl sulfate (SDS) were purchased from Beijing Solarbio Science \& Technology Co., Ltd. hUC-MSCs used for injection (CD73, CD90, and CD105 positive rates $\geq 95 \%$ ) were acquired from the Department of Hematology, Shaanxi Provincial People's Hospital, with the production batch number: 20190702.

\section{PREPARATION OF LCWE}

L. casei routine culture in MRS lactic acid bacteria broth medium and was identified by mass spectroscopy (MALDI-TOF, Bruker Corporation, USA). Bacteria were collected in the logarithmic phase by adding 4\% SDS lysis overnight. After being washed with phosphate buffer solution (PBS) and centrifuged, $250 \mu \mathrm{g} / \mathrm{mL}$ RNAse, DNAse, and Trypsin was sequentially added at $37{ }^{\circ} \mathrm{C}$ for $4 \mathrm{~h}$. After being washed with PBS and centrifuged, the collected bacterial debris was mixed with $5 \mathrm{~mL}$ PBS was added per $1000 \mathrm{mg}$ wet weight, and ultrasonic lysis 
was carried out for $2 \mathrm{~h}$ under dry ice water bath. The supernatant collected after centrifugation was LCWE, and the content of rhamnose in the supernatant was determined by the phenol sulfate colorimetric method.

\section{ESTABLISHMENT AND GROUPING OF KD MICE}

Sixty BALB/C mice were randomly divided into three groups: control group, model group, and stem cell group, with 20 mice in each group. Mice in the model and stem cell groups were intraperitoneally injected LCWE at a concentration of $1 \mathrm{mg} / \mathrm{mL}$ and $0.3 \mathrm{~mL} /$ time/ mouse, for 2 days (Matundan et al. 2019; Suganuma et al. 2020), while the mice in the control group were injected with PBS. From the 16th day of modeling onward, the control and model groups received $300 \mu \mathrm{L}$ PBS injected intraperitoneally daily, and the stem cell group received hUC-MSCs $300 \mu \mathrm{L}\left(10^{5} / \mathrm{mL}\right)$ injected intraperitoneally daily, both for 10 days. Referring to previous studies (Qin et al. 2006) on pathological changes in KD model mice, echocardiography and pathological changes in coronary arteries in the acute phase in each group were observed at days $4,15,26$, and 32 after intraperitoneal injection of LCWE.

\section{OBSERVATION OF PATHOLOGICAL INDEXES IN MICE}

The general conditions of mice were observed and recorded daily, including body weight $(\mathrm{g})$, food intake $(\mathrm{g})$, water intake $(\mathrm{mL})$, and hair changes. After echocardiography or sudden death, the heart was immediately dissected, and histochemical pathological sections were generated using a multi-function dyeing machine (BONDRX, Shanghai Leica Biosystems Co., Ltd.), and pathological changes in coronary arteries, including any presence of coronary artery aneurysm, thrombosis, or other formations, were observed using a pathological graphic processing system (Nikon Instrument, Shanghai, Co., Ltd.).

\section{HIGH RESOLUTION ECHOCARDIOGRAPHY OF THE MOUSE HEART}

After anesthetizing the mice with isoflurane gas, a depilating cream was applied to the left anterior chest area, and the hair was wiped clean with a tampon after $1 \mathrm{~min}$. The mice in the supine position and the chest were coated with an ultrasonic coupling agent. Ultrasonographic detection was carried out using a smallanimal high-resolution ultrasound imaging system (VisualSonics 2100, Fuji Photo Film, China, Investment
Co. Ltd.), and the long and short axis sections of the parasternal left ventricle were selected for examination. The internal diameter measurements of the left and right main coronary arteries were measured and recorded $4,15,26$, and 32 days after intraperitoneal injection of LCWE. The tumor area and size were measured in the presence of aneurysmal dilatation of the coronary artery. The diagnostic criteria for coronary artery aneurysms are based on the clinical criteria for coronary artery aneurysms established by the American Heart Association, namely the ratio of the internal diameter of the coronary artery dilatation segment to the internal diameter of the adjacent segment $>1.5$. Three consecutive cardiac cycles were selected. Ultrasonic storage parameters of mice were extracted and measured using the Vevo 770 software.

\section{RESULTS}

\section{ECHOCARDIOGRAPHY AFTER MOUSE MODELING AND STEM CELL INTERVENTION}

High frequency small animal echocardiography showed that $57.5 \%(23 / 40)$ of the model mice had coronary artery lesions, and 5\% (2/40) had right coronary artery aneurysm with an inner diameter of $0.918 \mathrm{~mm}$. The coronary artery wall and intima were thickened, and the inner diameter of the main trunk of the left coronary artery was widened. Moreover, the internal diameter of the main trunk of the left coronary artery decreased after stem cell intervention (Figure 1).

\section{HISTOPATHOLOGICAL CHANGES IN CORONARY ARTERIES}

After LCWE intra-abdominal injection, inflammatory reactions were observed in the coronary arteries of mice, and neutrophils, macrophages, and a small number of lymphocytes were infiltrated. Moreover, the elastic membrane of the blood vessels was destroyed, and focal fibrinoid necrosis and varying degrees of fibrosis were observed in the outer membrane (Figure 2).

\section{DISCUSSION}

Studies suggest that inflammation of small and medium vessels is the main pathological change associated with KD. Moreover, the long-term presence of vascular inflammation is the basis for the eventual complication of coronary atherosclerosis. However, the pathogenesis of $\mathrm{KD}$ is unclear at this stage and may be related to the presence of infection, the environment, genetic 

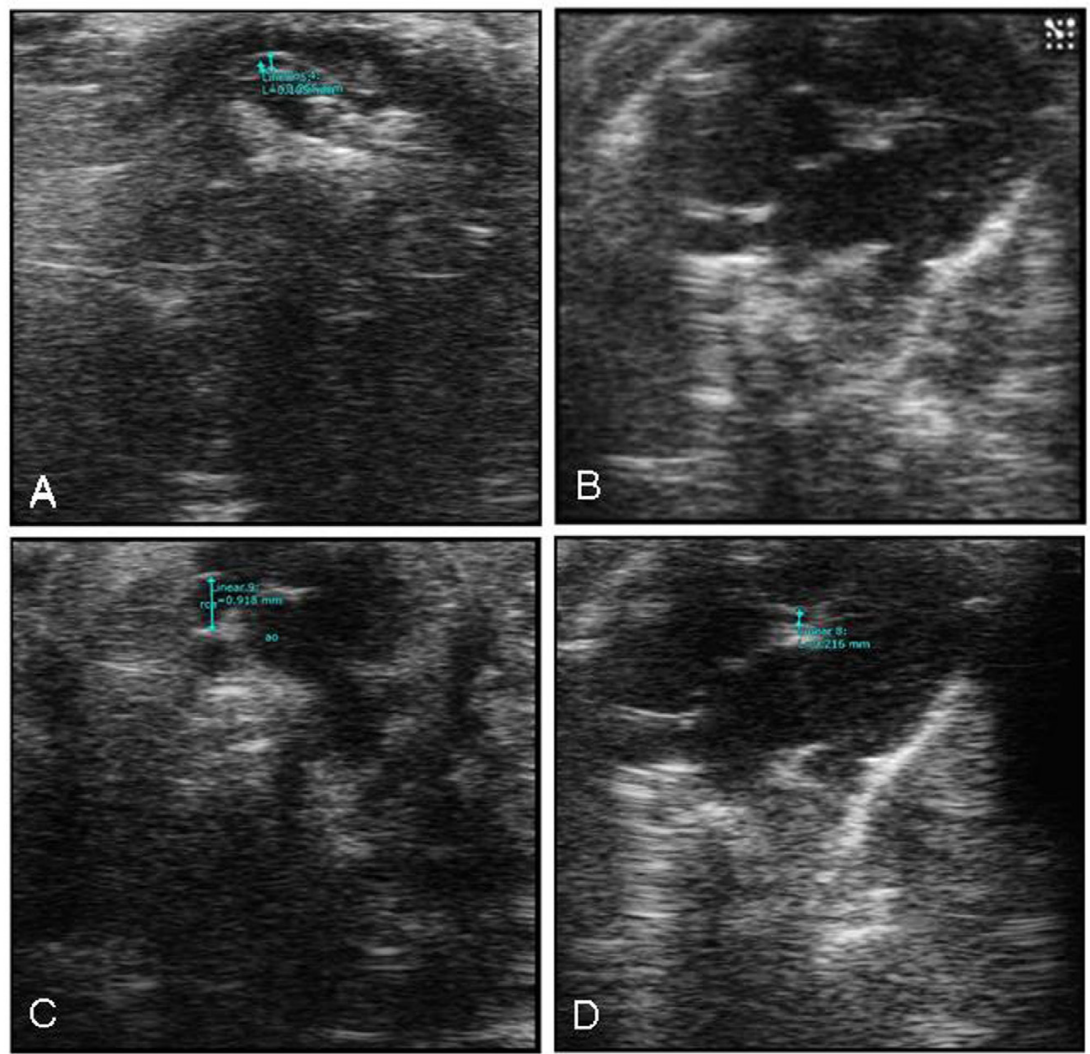

FIGURE 1. Echocardiography, A) After 4 days of LCWE injection, the inner diameter of the main trunk of the left coronary artery widened by approximately $0.255 \mathrm{~mm}$, and the intima thickened by $0.105 \mathrm{~mm}$; B)

The coronary arteries were significantly widened after 15 days of LCWE injection; C) Right coronary artery aneurysm appeared in mice after 24 days of LCWE injection; and D) The inner diameter of the main trunk of the left coronary artery decreased after $10 \mathrm{~d}$ of stem cell intervention

susceptibility, T-cell mediated immune response, and endothelial dysfunction (Sasawatari et al. 2020). At present, KD models have been established in animals, including mice, rabbits, pigs, and dogs; among which the most commonly used mouse strains include $\mathrm{C} 57 \mathrm{BL} / 6 \mathrm{~J}$, $\mathrm{C} 3 \mathrm{H} / \mathrm{HeN}, \mathrm{CDI}, \mathrm{DBA} / 2 \mathrm{~N}$, and BALB/C. The main inducers of the KD mouse model are $L$. casei cell wall extract and Candida albicans extract (Dou et al. 2013), both of which provide valuable experimental materials for KD research.

In this study, a mouse immune vasculitis model was established to simulate the changes in coronary inflammation associated with KD, and the dynamic changes of coronary artery endothelium were observed. Vascular endothelial cells, which cover the intimal surface of blood vessels, are the most closely interacting parts of blood vessel tissues and internal blood inflammatory factors. Endothelial cell injury and dysfunction may be an early indicator of the severity and outcome of KD disease. Further development of KD vascular inflammation can lead to the destruction of smooth muscle and the inner elastic layer of the vessel wall, leading to coronary artery dilatation and aneurysm (Kim et al. 2020).

The clinically recognized treatment method of $\mathrm{KD}$ is intravenous immunoglobulin or gamma globulin (IVIG) and oral aspirin. Although the combined treatment has been shown to significantly reduce mortality and coronary artery complications, IVIG-resistant cases have increased year-by-year, and myocardial infarction has become a major public health problem worldwide. Clinical trials have shown that stem cell therapy can improve cardiac function, can reduce infarct size and mortality, and has become a focus of cardiovascular disease research (Uchimura et al. 2020). Stem cells have a strong self-renewal ability and multiple differentiation potential and have unique biological characteristics. 

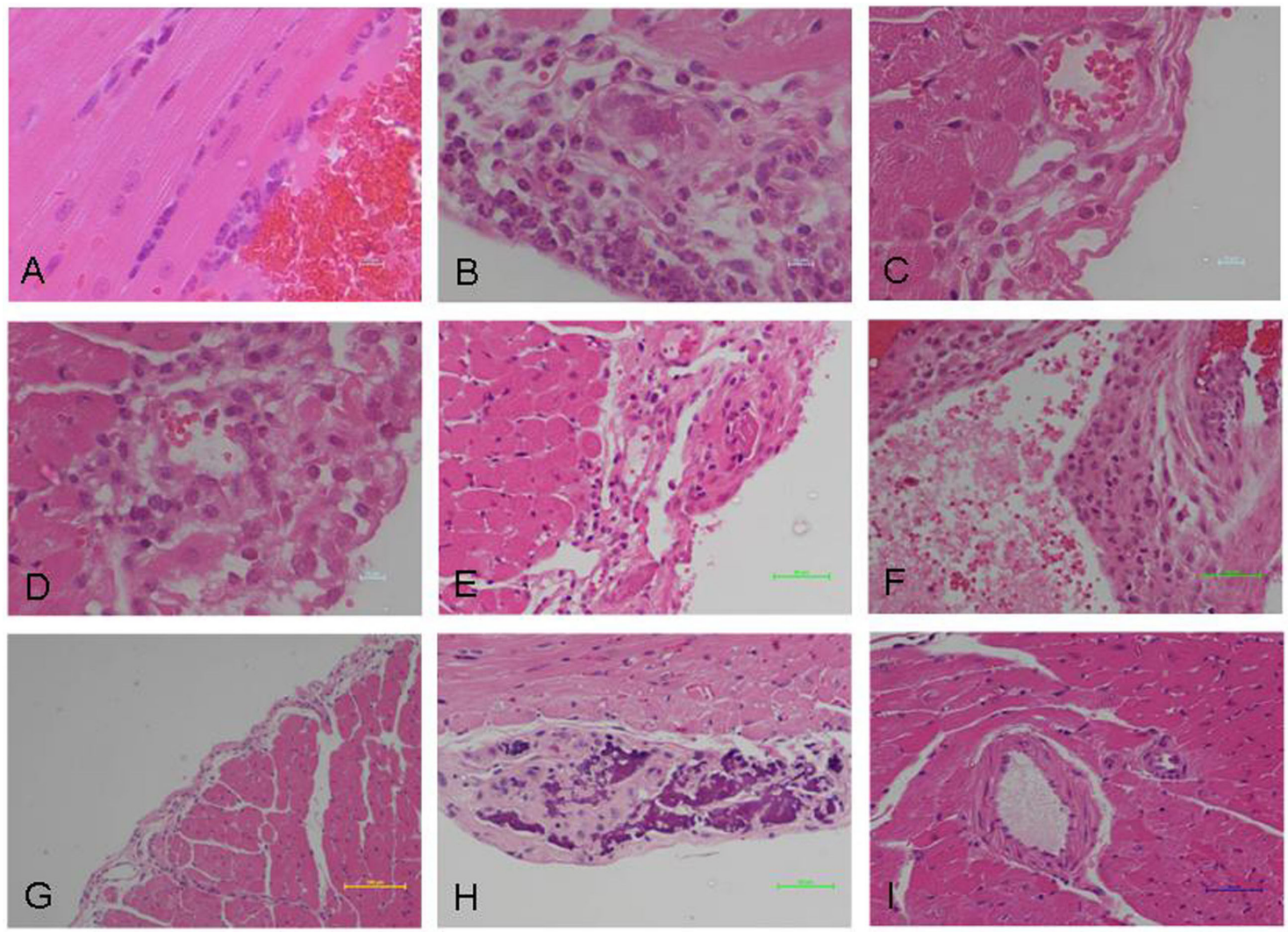

FIGURE 2. Pathological staining of the mouse heart, After 4 days of LCWE injection, local endothelial cells in the intima of the left ventricle exfoliation, and a white thrombus formed on the endothelium. Neutrophils were occasionally observed locally between the intima and the muscle wall (A); The epicardium of the right ventricle and atrium was highly swollen. A large number of neutrophils and a small number of monocytes (B, C, and E) can be seen; The inner (right) coronary artery lumen dilates and a small number of myocardial cells suffered necrotic collapse $(\mathrm{C}, \mathrm{D})$; The wall of the coronary artery was thickened and the lumen was narrowed, with white thrombus formation in the lumen (E); The aortic and mitral valves were mildly swollen with a few scattered infiltrating neutrophils (F); After 15 days of LCWE injection, we observed epicardial interstitial edema, some lymphocyte infiltration, diffuse mild hyperplasia of fibrous connective tissue $(\mathrm{G})$; and significant local hyperplasia of fibrous connective tissue accompanied by solid calcium salt deposits $(\mathrm{H})$; After the hUC-MSCs intervention for 10 days, numerous lymphocytes, eosinophilic granulocytes, and mononuclear cells were observed locally in the outer membrane of the left atrial appendage (I); No obvious vascular inflammatory reaction or other obvious abnormalities were observed. Magnification: A-E, 40 ×; F, H, 20 ×; G, $10 \times$; I, $200 \times$

hUC-MSCs have gradually gained the favor of clinical researchers due to their wide sources, low immune response, and multi-differentiation potential given that they can differentiate into osteoblasts, lipids, fibroblasts, endothelial cells, cardiomyocytes, and other cells (Arutyunyan et al. 2016).

In this study, after intraperitoneal injection of LCWE in mice, echocardiography showed that 57.5\% $(23 / 40)$ of the mice had coronary artery lesions; of which $5 \%(2 / 40)$ had right coronary artery aneurysm, and $27.5 \%$
(11/40) had thickening of the intima and coronary artery wall, and a widened inner diameter of the main artery of the left coronary artery. Histopathological examination showed slight swelling of the epicardium of the aortic valve, mitral valve, right ventricle and atrium, scattered infiltration of a few neutrophils, dilatation of the inner (right) coronary artery lumen, necrosis and disintegration of a few cardiomyocytes, and significant local proliferation of fibrous connective tissue with solid calcium salt deposits. Following stem cell intervention, 
echocardiography showed a decrease in the inner diameter of the main coronary artery, and pathological examination showed multiple lymphocytes, eosinophils, and monocytes infiltrating in the outer membrane of the left auricle. No obvious vascular inflammatory reaction or other obvious abnormalities was observed. These results indicated that hUC-MSCs intervention could significantly reduce $\mathrm{KD}$-like coronary artery injury in mice induced by LCWE. Echocardiography has the advantage of being fast and noninvasive and has a higher accuracy for intramural coronary arteries than CT and angiography. Histopathology is the 'gold standard' for cardiac coronary examination, and combined with echocardiography to examine the coronary pathological changes in the heart of mice after modeling and intervention treatment, the combination of the speed of echocardiography and the slowness of histopathology can be achieved with high accuracy and efficiency, which provides sufficient technical support for the prevention and treatment of KD.

This study has some limitations. First, the experimental time was relatively short, and we could not completely simulate the occurrence, development, and prognosis of coronary artery injury in the LCWEinduced KD animal model. Second, the effect of hUCMSCs on inhibiting coronary artery lesions in animal models of KD has not been studied from a dose-dependent perspective. Thus, these limitations represent outstanding issues for future research.

\section{CONCLUSION}

In this study, we not only successfully induced changes in coronary artery lesions similar to KD in experimental mice but also proved that the intervention of hUCMSCs could reduce the degree of inflammation of coronary artery lesions in mice. These findings provide an experimental basis for the use of hUC-MSCs in the treatment of coronary artery injury resulting from KD.

\section{ACKNOWLEDGEMENTS}

This study was supported by the International Science and Technology Cooperation Program Project of Shaanxi Province (grant number 2018KW-041) and the Key Research and Development Project of Shaanxi Province (grant number 2019SF-112). In this work, Hua Guo, Fuyong Jiao and Haixiang Zhang contributions to design the experiments, involved in drafting the manuscript; Xiaoyong Zhang, Yangmeng Feng, Yang Liu, Daoyan Liang and Xiaohua Yan contributions to conduct the experiments or acquisition of data, or analysis and interpretation of data; Hua Guo and Haixiang
Zhang revising it critically for important intellectual content; and have given final approval of the version to be published. We gratefully acknowledge the Shaanxi Engineering Research Center of Cell Immunology for their generous assistance, as well as to Yamei Shen and $\mathrm{Yu} \mathrm{Ma}$ for their invaluable cooperation in the research process. All authors declare no conflict of interest. All experiments were approved by the Ethics Committee for Animal Experimentation of Shaanxi Provincial People's Hospital.

\section{REFERENCES}

Abbaszadeh, H., Ghorbani, F., Derakhshani, M., Movassaghpour, A. \& Yousefi, M. 2020. Human umbilical cord mesenchymal stem cell-derived extracellular vesicles: A novel therapeutic paradigm. Journal of Cellular Physiology 235(2): 706-717.

Arutyunyan, I., Elchaninov, A., Makarov, A. \& Fatkhudinov, T. 2016. Umbilical cord as prospective source for mesenchymal stem cell-based therapy. Stem Cells International 2016: 6901286.

Dallaire, F., Fortier-Morissette, Z., Blais, S., Dhanrajani, A., Basodan, D., Renaud, C., Mathew, M., De Souza, A.M., Dionne, A., Blanchard, J., Saulnier, H., Kaspy, K., Rachedd'Astous, S., Dahdah, N., McCrindle, B.W., Human, D.G. \& Scuccimarri, R. 2017. Aspirin dose and prevention of coronary abnormalities in Kawasaki disease. Pediatrics 139(6): e20170098.

Dou, J., Li, H., Sun, L., Yan, W., Lv, H. \& Ding, Y. 2013. Histopathological and ultrastructural examinations of rabbit coronary artery vasculitis caused by bovine serum albumin: An animal model of Kawasaki disease. Ultrastructural Pathology 37(2): 139-145.

Kim, H.J., Kim, J.J., Yun, S.W., Yu, J.J., Yoon, K.L., Lee, K.Y., Kil, H.R., Kim, G.B., Han, M.K., Song, M.S., Lee, H.D., Ha, K.S., Hong, Y.M., Jang, G.Y., Lee, J.K. \& Korean Kawasaki Disease Genetics Consortium. 2020. Association of the IL16 Asn1147Lys polymorphism with intravenous immunoglobulin resistance in Kawasaki disease. Journal of Human Genetics 65(4): 421-426.

Li, L., Jaiswal, P.K., Makhoul, G., Jurakhan, R., Selvasandran, K., Ridwan, K. \& Cecere, R. 2017. Hypoxia modulates cell migration and proliferation in placenta-derived mesenchymal stem cells. Journal of Thoracic and Cardiovascular Surgery 154(2): 543-552.

Lo, M.S. 2020. A framework for understanding Kawasaki disease pathogenesis. Clinical Immunology 214: 108385.

Lo, M.S. \& Newburger, J.W. 2018. Role of intravenous immunoglobulin in the treatment of Kawasaki disease. International Journal of Rheumatic Diseases 21(1): 64-69.

Matundan, H.H., Sin, J., Noval Rivas, M., Fishbein, M.C., Lehman, T.J., Chen, S., Gottlieb, R.A., Crother, T.R., Abe, M. \& Arditi, M. 2019. Myocardial fibrosis after adrenergic 
stimulation as a long-term sequela in a mouse model of Kawasaki disease vasculitis. JCI Insight 4(3): e126279.

Muheremu, A., Sun, J.G., Wang, X.Y., Zhang, F., Ao, Q. \& Peng, J. 2016. Combined use of Y-tube conduits with human umbilical cordstem cells for repairing nerve bifurcation defects. Neural Regeneration Research 11(4): 664-669.

Nakayama, Y., Komatsu, J., Nishimura, Y., Fujita, T. \& Doi, Y.L. 2020. Kawasaki disease: Acute myocardial infarction of adult-onset associated with a giant coronary artery aneurysm. Journal of the American College of Cardiology 75(11_ Supplement_1): 2362.

Noval Rivas, M., Lee, Y., Wakita, D., Chiba, N., Dagvadorj, J., Shimada, K., Chen, S., Fishbein, M.C., Lehman, T.J., Crother, T.R. \& Arditi, M. 2017. CD8+ T cells contribute to the development of coronary arteritis in the Lactobacillus casei cell wall extract-induced murine model of Kawasaki disease. Arthritis \& Rheumatology 69(2): 410-421.

Perea-Gil, I., Monguió-Tortajada, M., Gálvez-Montón, C., Bayes-Genis, A., Borràs, F.E. \& Roura, S. 2015. Preclinical evaluation of the immunomodulatory properties of cardiac adipose tissue progenitor cells using umbilical cord blood mesenchymal stem cells: A direct comparative study. BioMed Research International 2015: 439808

Qin, L.J., Niu, M.Z., Wang, H.W., Shi, H. \& Cheng, P.X. 2006. Experimental study on coronary arteritis induced by immunization of mice with Lactobacillus casei cell wall extract. Journal of Applied Clinical Pediatrics 21(20): 1388-1391.

Sasawatari, S., Okamoto, Y., Kumanogoh, A. \& Toyofuku, T. 2020. Blockade of N-Glycosylation promotes antitumor immune response of T cells. Journal of Immunology 204(5): 1373-1385.

Suganuma, E., Sato, S., Honda, S. \& Nakazawa, A. 2020. A novel mouse model of coronary stenosis mimicking Kawasaki disease induced by Lactobacillus casei cell wall extract. Experimental Animals 69(2): 233-241.

Suzuki, E., Fujita, D., Takahashi, M., Oba, S. \& Nishimatsu, H. 2017. Therapeutic effects of mesenchymal stem cellderived exosomes in cardiovascular disease. Advances in Experimental Medicine and Biology 998: 179-185.
Tanaka, H., Yanai, C., Miura, N.N., Ishibashi, K., Yamanaka, D., Ohnishi, H., Ohno, N. \& Adachi, Y. 2020. Coronary vasculitis induced in mice by cell wall mannoprotein fractions of clinically isolated Candida species. Medical Mycology Journal 61(3): 33-48.

Uchimura, R., Ueda, T., Fukazawa, R., Hayakawa, J., Ohashi, R., Nagi-Miura, N., Ohno, N., Migita, M. \& Itoh, Y. 2020. Adipose tissue-derived stem cells suppress coronary arteritis of Kawasaki disease in vivo. Pediatrics International 62(1): 14-21.

Yan, J.R., Xie, L.J., Wang, J.Y., Xiao, T.T. \& Huang, M. 2012. Mice model of coronary artery lesion induced by Candida albicans water soluble fraction. Journal of Clinical Pediatric 30(2): 172-178.

Hua Guo \& Daoyan Liang

Clinical Laboratory of Shaanxi Provincial People's Hospital Xi'an 710068

China

Fuyong Jiao \& Xiaohua Yan

Children's Hospital of Shaanxi Provincial People's Hospital Xi'an 710068

China

Xiaoyong Zhang

The First Affiliated Hospital of Xi' an Medical University

Xi'an 710077

China

Yangmeng Feng, Yang Liu \& Haixiang Zhang*

Shaanxi Engineering Research Center of Cell Immunology Central Laboratory of Shaanxi Provincial People's Hospital Xi'an 710068

China

*Corresponding author; email: 307706698@qq.com

Received: 22 March 2021

Accepted: 2 July 2021 